this being the equivalent of banking fees, so effectively rendering the payment net to the recipient. The lists will include all results and now cover 6 pages per issue, to be expanded soon. Dues are payable to SSDF, Swedish postal giro no 418772 - 0, accessible through any bank. The information is based on about 300 tournament games each month. All other information may be obtained by writing to Göran Grottling, Diabasvägen 3, S 43700 Lindome / Sweden.

\title{
CONSTITUTION AND BY-LAWS
}

\author{
The Board of ICCA
}

From now on, the ICCA will publish the Constitution and the By-Laws every three years in order to inform the ICCA members of the formal status of the Association.

The Constitution and By-Laws were first published in the ICCA Newsletter, Vol. 2, No. 2, pp. 18-19 as a proposal. They were approved at the first ICCA Triennial Meeting in Linz, Austria on Sunday, September 28 , 1980, during the $3^{\text {rd }}$ World Computer-Chess Championship. Accepted amendments since are noted below and documented in footnotes as necessary.

\section{CONSTITUTION}

Article I: Name

The name of this organization shall be the International Computer Chess Association.

\section{Article II: Object}

The organization is a non-profit group devoted to providing an international framework for activities in computer chess and encouraging advances in this field.

\section{Article III: Qualification of Members}

Members in the ICCA are individuals. ${ }^{1)}$ Membership is open to anyone interested in pursuing the objectives of the organization as stated in Article II, who makes application and pays current dues.

\section{Article IV: Officers and their Election}

The elective officers, their terms, and their duties shall be as set forth in the By-Laws.

\section{BY-LAWS}

\section{Article I: Membership}

Section 1. General Membership. General Membership shall be as set forth in the Constitution.

Section 2. Honorary Membership. Honorary Membership may be awarded by vote at general meetings to any person who has especially aided the organization.

1 By decision of the 1986 Triennial Meetıng in Cologne, West Germany, Institutional Membershıp has been created next to individual membership (see ICCA Joumal, Vol 8, No 4, pp. 207-208). 


\section{Article II: Meetings}

Section 1. The World Championship and the Triennial Meeting. The ICCA will hold a World Computer Chess Championship every three (3) years. The first championship to be held under ICCA auspices will be in 1980. The Triennial Meetıng will take place during and at the site of the World Championship.

Section 2. Other Meetings. Other meetıngs of the ICCA may be called from time to tume to be held concurrent with and at the site of major international computer chess tournaments.

Section 3. Quorum. A quorum at the Triennial Meeting will consist of at least twenty (20) members.

\section{Article III: Officers}

Section 1. Elective Officers. The elective officers of the organization shall consist of a President, VicePresident and Secretary-Treasurer They shall constitute the Executive Committee of the organization and shall be charged with the administrative affairs of the ICCA.

Section 2. Elections. Elections for the members of the Executive Committee will be held at each Triennial Meetıng, with elected officers taking on their duties at the end of that meetıng Nominations are to be made by petition no later than three (3) months before the elections. The ICCA Journal ${ }^{2}$ will announce the candidates at least two (2) months before the election At least five (5) member signatures are required on each nominatıng petition All candidates for election must have been members of the ICCA for no less than two (2) years. Officers are elected by a majority of those present and votung, via secret, written ballot. Runoffs will be held if no candidate receives a simple majority. The candidate with the least votes will be eliminated from the ballot for each runoff, untıl one candidate receives the simple majority.

Section 3. Terms of Office. All members of the Executive Committee serve for a three-year term.

Section 4. Executive Committee. The Executıve Committee shall be presided over by the President.

\section{Article IV: Standing Committees}

Section 1. Chairmen. Committee Chairmen are appointed for a three-year term by the Executıve Committee.

Section 2. Standing Committees. Standing Committees shall be the Publications Board, the Rankıng Committee, the Tournament Organizing Committee, the Sanctioning Committee, the Program Rights Committee, the Standards Committee, and the Liaison Committee.

Section 3. Publications Board. The Publications Board will encourage the publication of technical and non-technical works on the subject of computer chess. The official publication of the ICCA shall be the ICCA Journal

Section 4. Ranking Committee. The Rankıng Commıttee will establısh a ratıng or rankıng system for programs and will rank and rate actıve programs.

Section 5. Tournament Organizing Committee. The Tournament Organızıng Committee will assist local organizers to the degree necessary with ICCA-sanctioned events This committee will organize the World Championship (see Article II, Section 1 of the By-Laws). 
Section 6. Sanctioning Committee. The Sanctioning Committee will give formal ICCA recognition to appropriate events. It will also decide on the tıme and place of the World Championship subject to Article II, Section 1 of the By-Laws.

Section 7. Program Rights Committee. The Program Rights Committee will decide on matters related to the rights of an individual to use a given program in ICCA-sanctioned events.

Section 8. Standards Committee. The Standards Committee will look into the problem of developing program input/output to facilitate the automation of computer-chess match play.

Section 9. Liaison Committee. The Liaison Committee will seek to establish appropriate ties with other organizations. Any formal tes must be voted upon at the Triennial Meetıng (see Article II, Section 1 of the By-Laws).

\section{Article V: Council}

Section 1. Council Membership. The governing body of the ICCA shall be the Council. The Council shall consist of the President, Vice-President, Secretary-Treasurer and the Chairmen of the Standing Committees.

Section 2. Council Organization. The Council shall be presided over by the President.

\section{Article VI: Dues and Finances}

Section 1. Annual Dues. Dues will be twenty-five dollars (\$25.00) in United States currency per year payable in advance. Dues are collected during the month of January. ${ }^{3}$ )

Section 2. Disposition of Funds. No part of the net earnings of the ICCA shall ever inure to or for the benefit of or be distributed to its members, officers or private persons, except that the ICCA shall be empowered to pay reasonable compensation for services rendered, and to make payments and distributions in furtherance of the exempt purposes for which it was founded.

\section{Article VII: Amendment of the By-Laws}

Section 1. Presentation. A request for changes to the By-Laws must be made by written petition of at least five (5) members. Petitions must be made no later than three (3) months before the elections. The ICCA Journal will announce the proposed amendments at least two (2) months before the elections.

Section 2. Voting on Proposed Amendments. Proposed amendments to the By-Laws will become a part of the ballot which includes those running for elected offices. All procedures for voting such a change are the same as for electing officers, except that two-thirds of the members voting and present must support the change.

\section{Article VIII: Dissolution}

Section 1. Dissolution of the ICCA. Upon winding up and dissolution of the ICCA, after paying or adequately providing for the debts and obligations of this organization, the remaining assets shall be distributed to a non-profit fund, foundation, or corporation whose purposes are consistent with the Object of this organization. 